https://doi.org/10.35339/ekm.2019.83.02.07

УДК 616.89-008.48:616-05:616.17-008.1:616.831-005.]-08+615.851+616-084

\title{
Т.П. Яворська
}

Харківська медична академія післядипломної освіти

\section{ЖИТТЕСТІЙКІСТЬ ЯК СКЛАДОВА ПСИХОЛОГІЧНОЇ АДАПТАЦІЇ У ПАЦІЄНТІВ 3 ЦЕРЕБРОВАСКУЛЯРНОЮ ПАТОЛОГІЄЮ}

\begin{abstract}
Обстежено 383 пацієнти з цереброваскулярною патологією на різних етапах розвитку захворювання та 47 умовно здорових осіб. У дослідженні використано «Тест життєстійкості за С. Мадді» та Бостонський тест на стресостійкість. У пацієнтів з розгорнутою клінічною картиною цереброваскулярної патології визначаються нижчі показники життєстійкості. Хворі після інсульту складають групу найвищого ризику щодо порушення психологічної адаптації внаслідок поєднання комплексу дезадаптивних соматопсихологічних чинників. Підвищення стресового ризику поєднується зі зниженням життєстійкості, що вказує на наявність спільних ланок психогенезу або чинників, задіяних у «антистресовій» активності. Розуміння проявів психологічного феномена життєстійкості як внутрішньоособистісного ресурсу щодо подолання стресу у пацієнтів з соматичними захворюваннями, розкриває широкі можливості у побудові комплексу заходів медико-психологічної допомоги для пацієнтів з цереброваскулярною патологією на основі здоров'яцентрованого підходу.

Ключові слова: життєстійкість, ичеребровасулярна патологія, медико-психологічна допомога.
\end{abstract}

\section{Вступ}

Цереброваскулярна патологія (ЦВП) має важливе значення для медичної практики у зв'язку з вітальною загрозою хвороби, розвитком ускладнень, що важко піддаються лікуванню та відновленню (рухові, мовні розлади), та медико-психологічної сфери - внаслідок порушення психічного здоров'я пацієнтів та зміну їх психосоціального статусу [1-3].

Серцево-судинні захворювання відіграють одну з провідних ролей у розвитку ЦВП [3]. Проте спектр патологічних станів, які формують патофізіологічний фон для розгортання хвороби, досить широкий: ожиріння, цукровий діабет, васкуліти, дисфункція системи згортання крові, остеохондроз, черепно-мозкові травми $[4,5]$. Важливе значення у розвитку ЦВП мають психологічні та психосоціальні чинники, що пов'язані з особливостями особистості, способами подолання стресових ситуацій, прихильністю до лікування, дотриманням здорового способу життя [6-10].
Життєстійкість, як один із психологічних факторів задіяних у відреагуванні на стресову ситуацію, в даному випадку хворобу, виступає складним психологічним феноменом, який описує особливий психологічний ресурс, що проявляється через відношення до світу, його сприйняття, дій у відповідь залежно від включення у потік подій, відчуття суб'єктивного контролю і можливості змінювати реальність, приймати виклики та ризики.

Вивчення прояву феномена життєстійкості у пацієнтів з ЦВП є важливою складовою у розумінні особливостей ії розвитку та перебігу в аспекті відреагування особистості на загрозливу ситуацію, якою постає хвороба, та відповідно розробки заходів медико-психологічної допомоги.

Мета дослідження - вивчити феномен життєстійкості у пацієнтів з цереброваскулярною патологією на різних етапах перебігу захворювання.

(C) Т.П. Яворська, 2019 


\section{Матеріал і методи}

На базі центру екстреної медичної допомоги та медицини катастроф Харківської обласної клінічної лікарні впродовж 2016-2018 років на основі інформованої згоди здійснено психодіагностичне обстеження 430 осіб. До основної групи (ОГ) входило 383 пацієнти на різних етапах розвитку захворювання: 122 хворі (Г1) з чинниками кардіоваскулярного ризику на фоні серцево-судинної патології (гіпертонічна хвороба - 59,8\% та ішемічна хвороба серця 40,2\%); 134 опитувані (Г2) з клінічними проявами ЦВП, що спостерігалися до 2 років; 127 осіб (ГЗ) після перенесеного мозкового інсульту у періоді від 6 міс. до 1,5 року. До групи порівняння (ГП) увійшло 47 умовно здорових осіб, у яких були відсутні фактори ризику ЦВП чи інші супутні соматичні захворювання.

Серед опитуваних 58,5 \% становили чоловіки та 41,5\% - жінки. Віковий діапазон учасників дослідження коливався від 37 до 68 років.

Вивчення життєстійкості у пацієнтів з ЦВП проводилося на основі «Тесту життєстійкості за С. Мадді» в адаптації Д.І. Леонтьєва та Є.I. Рассказової (Hardiness Survey).

Життєстійкість (hardiness) - це диспозиція, що включає 3 компоненти (залученість, контроль та прийняття ризику), які перешкоджають виникненню внутрішньої напруги в кризових ситуаціях за рахунок сприйняття події менш стресовою чи застосування ефективних способів копінгу.

Зміст залучення (commitment) полягає у тому, що включення у оточуючі події, відчуття зв'язку та приналежності до світу, задоволення від результату діяльності формують гарні можливості вирішити ситуацію та сприятливий психоемоційний фон.
Контроль (control) полягає у суб'єктивній переконаності в тому, що на результат, подію можна вплинути, реальність піддається змінам. Особистість 3 високим контролем як складовою життєстійкості переконана у тому, що вона керує своїм життям.

Прийняття ризику (challenge) - переконаність особистості в тому, що отриманий досвід (позитивний чи негативний) має важливе значення для іiї розвитку, розуміння себе та світу. Дана складова життєстійкості відображає готовність діяти в умовах ризику, приймаючи факт невідомості як частину ситуації, відсутності гарантій позитивного результату. В основі прийняття ризику лежить ідея розвитку через активне засвоєння знань 3 досвіду.

Поділ на групи в залежності від рівня стресового ризику - помірного, високого, надвисокого - здійснювався на основі Бостонського тесту на стресостійкість (тест Аналізу стилю життя). Статистична обробка проводилася з використанням MS Excel v.8.0.3.

Результати та їх обговорення

Розподіл досліджуваних груп за загальним показником життєстійкості виявив високі результати у $36,2 \%$ у ГП, $31,1 \%$ у Г1, 25,4 \% у Г2 та 19,7 \% у ГЗ, середні - відповідно 55,3\%, $52,5 \%, 52,2 \%$ та 54,3\% та низькі - 8,5\%, $16,4,22,4$ та 26,0 \% (табл. 1).

У структурі залученості високі показники становили від 23,6 до 36,2 \%, середні - від 50,0 до 51,2 \%, та низькі - від 12,8 до $25,2 \%$. Щодо складової контролю діагностовано високі результати у діапазоні від 18,9 до 31,9\%, середні - від 50,7 до 55,3 \%, низькі - від 12,8 до $29,1 \%$. Прийняття ризику з високими показниками спостерігалося від 18,9 до 31,9 \% опитуваних, середніми - від 49,2 до 53,2 \%, та низькими - від 14,9 до $28,3 \%$.

Таблиия 1. Загальна структура життєстійкості у досліджуваних групах, \%

\begin{tabular}{|c|c|c|c|c|}
\hline Складова / Рівень & Залученість & Контроль & Прийняття ризику & Загальна життєстійкість \\
\hline \multicolumn{5}{|c|}{$\Gamma \Pi, \mathrm{n}=47$} \\
\hline Низький & 12,8 & 12,8 & 14,9 & 8,5 \\
\hline Середній & 51,1 & 55,3 & 53,2 & 55,3 \\
\hline Високий & 36,2 & 31,9 & 31,9 & 36,2 \\
\hline \multicolumn{5}{|c|}{$\Gamma 1, n=122$} \\
\hline Низький & 17,2 & 20,5 & 23,0 & 16,4 \\
\hline Середній & 50,0 & 50,8 & 49,2 & 52,5 \\
\hline Високий & 32,8 & 28,7 & 27,9 & 31,1 \\
\hline \multicolumn{5}{|c|}{$\Gamma 2, n=134$} \\
\hline Низький & 22,4 & 26,9 & 26,1 & 22,4 \\
\hline Середній & 50,7 & 50,7 & 50,7 & 52,2 \\
\hline Високий & 26,9 & 22,4 & 23,1 & 25,4 \\
\hline \multicolumn{5}{|c|}{$\Gamma 3, n=127$} \\
\hline Низький & 25,2 & 29,1 & 28,3 & 26,0 \\
\hline Середній & 51,2 & 52,0 & 52,8 & 54,3 \\
\hline Високий & 23,6 & 18,9 & 18,9 & 19,7 \\
\hline
\end{tabular}


Тенденція до зниження життєстійкості в опитуваних, які мали соматичне захворювання (Г2 та Г3), вказувала, з одного боку, на наявність ряду особистісно-поведінкових паттернів, задіяних у відреагуванні на стрес, 3 іншого - на більш негативну суб'єктивну оцінку власного ресурсу у стресовій ситуації (особливості сприйняття події та себе в ній).

Виявлено значну різницю у проявах життєстійкості поміж досліджуваними групами залежно від рівня стресового ризику (табл. 2). У опитуваних з помірним стресовим ризиком ситуацію, формувало песимістичне налаштування на результати лікування та нівелювало потребу модифікувати свої звички, а отже і діяти профілактично по відношенню до збереження свого здоров'я.

Результати щодо життєстійкості та ії складових у ГП та Г1 були подібними, тоді як порівняння з Г2 та Г3, тобто хворими з клінічно розгорнутою картиною ЦВП та її наслідками, окреслювало суттєву різницю.

Факт маніфестації захворювання, поява «видимих» симптомів (пацієнт самостійно зда-

Таблиия 2. Структура життєстійкості залежно від етапу розвитку ЦВП та рівня стресового ризику, \%

\begin{tabular}{|c|c|c|c|c|c|}
\hline \multicolumn{2}{|c|}{ Складова / Рівень } & Залученість & Контроль & Прийняття ризику & Загальна життєстійкість \\
\hline \multirow{4}{*}{ пСР } & Низький & 7,5 & 6,5 & 7,5 & 5,4 \\
\cline { 2 - 6 } & Середній & 49,5 & 53,8 & 52,7 & 49,5 \\
\cline { 2 - 6 } & Високий & 43,0 & 39,8 & 39,8 & 45,2 \\
\hline \multirow{3}{*}{ ВСР } & Низький & 20,5 & 25,8 & 26,2 & 20,1 \\
\cline { 2 - 6 } & Середній & 49,3 & 48,5 & 48,0 & 27,4 \\
\cline { 2 - 6 } & Високий & 30,1 & 25,8 & 25,8 & 33,3 \\
\hline \multirow{3}{*}{ нВСР } & Низький & 32,4 & 36,1 & 36,1 & 58,3 \\
\cline { 2 - 6 } & Середній & 54,6 & 56,5 & 56,5 & 8,3 \\
\cline { 2 - 6 } & Високий & 13,0 & 7,4 & 7,4 & \\
\hline
\end{tabular}

(ПСР) високі показники загального рівня життєстійкості визначені у 45,2\% осіб, тоді як 3 високим стресовим ризиком (ВСР) у $27,5 \%$ та надвисоким (нВСР) у $8,3 \%$. Середній рівень життєстійкості зареєстровано у $49,5 \%$ опитуваних у підгрупі з ПСР, $52,4 \%$ 3 ВСР та 58,3 \% - 3 нВСР. Щодо низьких результатів життєстійкості відмінності також значимі - у підгрупі з ПСР - 5,4 \%, з ВСР $320,1 \%$ та нВСР - 33,3\% респондентів.

Таким чином, підвищення рівня стресового ризику поєднувалось зі зниженням життєстійкості, що може вказувати на наявність в основі даних психологічних феноменів, спільних ланок психогенезу або чинників, задіяних у «антистресовій» активності.

У табл. 3-6 представлені результати розподілу складових життєстійкості залежно від рівня стресового ризику у кожній з досліджуваних груп окремо.

У континуумі «умовно здорові - особи 3 кардіоваскулярним ризиком - пацієнти, які мають клінічні прояви ЦВП - хворі після мозкового інсульту» в міру збільшення стресового ризику спостерігалося погіршення життестійкості за кожною складовою. Проте відчуття контролю та прийняття ризику знижувалися більш критично, що проявлялося інтенсивним відчуттям неможливості впливати на тен виявляти прояви нездоров'я) або ж настання тяжких ускладнень (рухові, мовні, когнітивні розлади) були потужним стресогенним пластом, який визначав та характеризував ресурс життєстійкості пацієнтів. Відсутність ефективних навичок протидії стресу - акцентованість на негативні події, ії катастрофізація, відчуття відокремленості від оточуючого світу, його непідконтрольності, ворожості, неготовність сприйняти і адаптуватися до будь-якого (навіть негативного) розвитку подій - особливо гостро визначалися в міру розгортання захворювання.

Найнижчі показники життєстійкості виявлені у пацієнтів з ГЗ, що відповідно вказувало на їх вищу вразливість та ризик розвитку психологічної дезадаптації. Значне зниження фізичних можливостей, залежність від оточення, зменшення автономії, складність процесу реабілітації і відсутність гарантій відновлення втрачених функцій були стресуючими факторами, які формували негативне ставлення до ситуації в цілому та своїх можливостей для подолання хвороби зокрема (негативна оцінка життестійкості).

\section{Висновки}

У пацієнтів з розгорнутою клінічною картиною цереброваскулярної патології визначаються нижчі показники життєстійкості. Хворі після інсульту складають групу найвищого 
Таблиия 3. Розподіл складових життєстійкості у ГП залежно від рівня стресового ризику, \%

\begin{tabular}{|c|c|c|c|c|c|}
\hline \multicolumn{2}{|c|}{ Складова / Рівень } & Залученість & Контроль & Прийняття ризику & Загальна життєстійкість \\
\hline \multirow{4}{*}{ пСР } & Низький & 5,6 & - & 5,6 & - \\
\cline { 2 - 6 } & Середній & 50,0 & 55,6 & 50,0 & 50,0 \\
\cline { 2 - 6 } & Високий & 44,4 & 44,4 & 44,4 & 50,0 \\
\hline \multirow{3}{*}{ ВСР } & Низький & 13,0 & 17,4 & 17,4 & 8,7 \\
\cline { 2 - 6 } & Середній & 52,2 & 52,2 & 32,2 & 36,5 \\
\cline { 2 - 6 } & Високий & 34,8 & 30,4 & 33,3 & 33,3 \\
\hline \multirow{3}{*}{ нВСР } & Низький & 33,3 & 33,3 & 66,7 & 66,7 \\
\cline { 2 - 6 } & Середній & 50,0 & 66,7 & - & - \\
\cline { 2 - 6 } & Високий & 16,7 & - & - & - \\
\hline
\end{tabular}

Примітка. ПСР - помірний стресовий ризик, $\mathrm{BCP}$ - високий стресовий ризик, нВСР - надвисокий стресовий ризик.

Таблиия 4. Розподіл складових життєстійкості у Г1 залежно від рівня стресового ризику, \%

\begin{tabular}{|c|c|c|c|c|c|}
\hline \multicolumn{2}{|c|}{ Складова / Рівень } & Залученість & Контроль & Прийняття ризику & Загальна життєстійкість \\
\hline \multirow{3}{*}{ пСР } & Низький & 8,8 & 5,9 & 8,8 & 5,9 \\
\cline { 2 - 6 } & Середній & 50,0 & 55,9 & 52,9 & 50,0 \\
\cline { 2 - 6 } & Високий & 41,2 & 38,2 & 38,2 & 44,1 \\
\hline \multirow{3}{*}{ ВСР } & Низький & 15,9 & 22,2 & 23,8 & 15,9 \\
\cline { 2 - 6 } & Середній & 47,6 & 46,0 & 46,0 & 50,8 \\
\cline { 2 - 6 } & Високий & 36,5 & 31,7 & 30,2 & 32,3 \\
\hline \multirow{3}{*}{ нВСР } & Низький & 32,0 & 36,0 & 40,0 & 60,0 \\
\cline { 2 - 6 } & Середній & 56,0 & 56,0 & 52,0 & 8,0 \\
\cline { 2 - 6 } & Високий & 12,0 & 8,0 & 8,0 & \\
\hline
\end{tabular}

Примітка. ПСР - помірний стресовий ризик, ВСР - високий стресовий ризик, нВСР - надвисокий стресовий ризик.

Таблиия 5. Розподіл складових життєстійкості у Г2 залежно від рівня стресового ризику, \%

\begin{tabular}{|c|c|c|c|c|c|}
\hline \multicolumn{2}{|c|}{ Складова / Рівень } & Залученість & Контроль & Прийняття ризику & Загальна життєстійкість \\
\hline \multirow{4}{*}{ пСР } & Низький & 8,0 & 8,0 & 8,0 & 8,0 \\
\cline { 2 - 6 } & Середній & 48,0 & 52,0 & 52,0 & 48,0 \\
\cline { 2 - 6 } & Високий & 44,0 & 40,0 & 40,0 & 44,0 \\
\hline \multirow{3}{*}{ ВСР } & Низький & 23,4 & 29,9 & 28,6 & 23,4 \\
\cline { 2 - 6 } & Середній & 50,6 & 48,1 & 48,1 & 24,7 \\
\cline { 2 - 6 } & Високий & 26,0 & 22,1 & 23,4 & 31,3 \\
\hline \multirow{3}{*}{ нВСР } & Низький & 31,3 & 34,4 & 34,4 & 56,3 \\
\cline { 2 - 6 } & Середній & 53,1 & 56,3 & 56,3 & 12,5 \\
\cline { 2 - 6 } & Високий & 15,6 & 9,4 & 9,4 & \\
\hline
\end{tabular}

Примітка. ПСР - помірний стресовий ризик, $\mathrm{BCP}$ - високий стресовий ризик, $\mathrm{HBCP}-$ надвисокий стресовий ризик.

Таблиия 6. Розподіл складових життєстійкості у ГЗ залежно від рівня стресового ризику, \%

\begin{tabular}{|c|c|c|c|c|c|}
\hline \multicolumn{2}{|c|}{ Складова / Рівень } & Залученість & Контроль & Прийняття ризику & Загальна життєстійкість \\
\hline \multirow{4}{*}{ пСР } & Низький & 6,3 & 12,5 & 6,3 & 6,3 \\
\cline { 2 - 6 } & Середній & 50,0 & 50,0 & 56,3 & 50,0 \\
\cline { 2 - 6 } & Високий & 43,8 & 37,5 & 37,5 & 43,8 \\
\hline \multirow{3}{*}{ ВСР } & Низький & 24,2 & 27,3 & 28,8 & 24,2 \\
\cline { 2 - 6 } & Середній & 48,5 & 50,0 & 48,5 & 22,0 \\
\cline { 2 - 6 } & Високий & 27,3 & 22,7 & 22,7 & 35,6 \\
\hline \multirow{3}{*}{ нВСР } & Низький & 33,3 & 37,8 & 35,6 & 57,8 \\
\cline { 2 - 6 } & Середній & 55,6 & 55,6 & 57,8 & 6,7 \\
\cline { 2 - 6 } & Високий & 11,1 & 6,7 & 6,7 & \\
\hline
\end{tabular}

Примітка. ПСР - помірний стресовий ризик, $\mathrm{BCP}$ - високий стресовий ризик, нВСР - надвисокий стресовий ризик. 
ризику щодо порушення психологічної адаптації внаслідок поєднання комплексу дезадаптивних сомато-психологічних чинників.

Підвищення стресового ризику поєднується зі зниженням життєстійкості, що вказує на наявність спільних ланок психогенезу або чинників, задіяних у «антистресовій» активності.
Розуміння проявів психологічного феномена життєстійкості як внутрішньоособистісного ресурсу для подолання стресу у пацієнтів з соматичними захворюваннями, розкриває широкі можливості у побудові комплексу заходів медико-психологічної допомоги для пацієнтів з цереброваскулярною патологією на основі здоров'яцентрованого підходу.

\section{Література}

1. Мищенко T. C. Эпидемиология цереброваскулярных заболеваний и организация помощи больным с мозговым инсультом в Украине // Український вісник психоневрології. - 2017. - Т. 25, вип. 1 (90). - C. 22-24.

2. Global and regional burden of stroke during 1990-2010: findings from the Global Burden of Disease Study 2010 / [V. L. Feigin, M. H. Forouzanfar, R. Krishnamurthi et al.] // Lancet. - 2014. - Vol. 383, № 9913. - P. 245-254.

3. Бабак О. Я., Дроздова В. І., Бабец̧ь А. А., Степанова Л. Г., Омельниц̧ька Л. В. Хвороби системи кровообігу в Україні як одна з характеристик суспільного здоров'я // Український терапевтичний журнал. - 2017. - № 1. - С. 4-11.

4. Фадєєнко Г. Д., Гріднєв О. Є., Несен А. О., Чернишов В. А., Грунченко М. М., Шкапо В. Л. Коморбідність і високий кардіоваскулярний ризик - ключові питання сучасної медицини // Український терапевтичний журнал. - 2013. - №1. - С. 102-107.

5. Маркова М. В., Бабич В. В. Медико-психологічні аспекти розвитку та перебігу хвороб системи кровообігу // Новости медицины и фармации. Неврология и психиатрия. Специализированный выпуск. - 2008. - № 243. - С. 71-74.

6. Маркова М. В., Бабич В. В., Степанова Н.М., Бахтіярова С.А., Лисенко І.О. Психосоціальний стрес та негативний вплив макро- й мікросоціальних чинників як складова розвитку хвороб системи кровообігу // Збірник наукових праць співробітників НМАПО ім. П.Л.Шупика. - 2008. № 4. - C. 336-348.

7. Стрес і хвороби системи кровообігу: посібник / за ред.: В. М. Коваленко, В. М. Корнацького. Київ: Коломішин В. Ю., 2015. 352 с.

8. Чапала T. В. Влияние психологических факторов на отягощение соматического состояния пациентов с ишемической болезнью сердца // Вестник Орловского государственного университета. - 2011. - № 5 (19). - C. 397-400.

9. Hussain S., Jamal S.Z., Qadir F. Medication Adherence In Post Myocardial Infarction Patients // J Ayub Med Coll Abbottabad. - 2018. - Vol. 30(4). - P. 552-557.

10. Du L., Cheng Z., Zhang Y., Li Y., Mei D. The impact of medication adherence on clinical outcomes of coronary artery disease: A meta-analysis // Eur J Prev Cardiol. - 2017. - Vol. 24(9). - P. 962-970.

\section{References}

1. Mishchenko T.S. (2017). Epidemiologiya tserebrovaskulyarnykh zabolevaniy i organizatsiya pomoshchi bol'nym s mozgovym insul'tom v Ukraine [Epidemiology of cerebrovascular diseases and organization of care for patients with cerebral stroke in Ukraine]. Ukrainskiy visnik psikhonevrologiiUkrainian News of Psychoneurology, vol. 25, № 1 (90), pp. 22-24 [in Russian].

2. Feigin V.L., Forouzanfar M.H., Krishnamurthi R. et al. (2014). Global and regional burden of stroke during 1990-2010: findings from the Global Burden of Disease Study 2010. Lancet., vol. 383, № 9913, pp. 245-254.

3. Babak O.Ya., Drozdova V.I., Babets A.A., Stepanova L.H., Omelnytska L.V. (2017). Khvoroby systemy krovoobihu v Ukraini yak odna z kharakterystyk suspilnoho zdorovia [Diseases of the circulatory system in Ukraine as one of the characteristics of public health]. Ukrainskyi terapevtychnyi zhurnalUkrainian Therapeutic Journal, № 1, pp. 4-11 [in Ukrainian].

4. Fadeenko H.D., Hridniev O.Ye., Nesen A.O., Chernyshov V.A., Hrunchenko M.M., Shkapo V.L. (2013). Komorbidnist i vysokyi kardiovaskuliarnyi ryzyk - kliuchovi pytannia suchasnoi medytsyny [Comorbidity and high cardiovascular risk - crucial issues in modern medicine]. Ukrainskyi terapevtychnyi zhurnal - Ukrainian Therapeutic Journal, № 1, pp. 102-107 [in Ukrainian].

5. Markova M.V., Babych V.V. (2008). Medyko-psykholohichni aspekty rozvytku ta perebihu khvorob systemy krovoobihu [Medico-psychological aspects of the development and course of diseases of the circulatory system]. Novosty medytsyny y farmatsyy. Nevrolohyya y psykhyatryya. Spetsyalyzyrovannyy 
vypusk. - News of medicine and pharmacy. Neurology and psychiatry. Specialized issue, № 243, pp. 71-74 [in Ukrainian].

6. Markova M.V., Babych V.V., Stepanova N.M., Bakhtiyarova S.A., Lysenko I.O. (2008). Psykhosotsialnyy stres ta nehatyvnyy vplyv makro- y mikrosotsialnykh chynnykiv yak skladova rozvytku khvorob systemy krovoobihu [Psychosocial stress and the negative impact of macro- and micro-social factors as a component of the development of diseases of the circulatory system]. Zbirnyk naukovykh prats spivrobitnykiv NMAPO im. P.L.Shupyka - Proceedings of NMAPE staff. PL Shupik, № 4, pp. 336-348 [in Ukrainian].

7. Kovalenko V.M., Kornatsky V.M. (Eds.). (2015). Stres i khvoroby systemy krovoobihu: posibnyk [Stress and diseases of the circulatory system: manual]. Kyiv: V. Kolomyshin, 352 p. [in Ukrainian].

8. Chapala T.V. (2011). Vliyaniye psikhologicheskikh faktorov na otyagoshcheniye somaticheskogo sostoyaniya patsiyentov s ishemicheskoy bolezn'yu serdtsa [The influence of psychological factors on the aggravation of the somatic state of patients with coronary heart disease]. Vestnik Orlovskogo gosudarstvennogo universiteta - Bulletin of the Oryol State University, № 5 (19). pp. 397-400 [in Russian].

9. Hussain S., Jamal S.Z., Qadir F. (2018). Medication Adherence In Post Myocardial Infarction Patients. J Ayub Med Coll Abbottabad. vol. 30 (4). pp. 552-557.

10. Du L., Cheng Z., Zhang Y., Li Y., Mei D. (2017). The impact of medication adherence on clinical outcomes of coronary artery disease: A meta-analysis. Eur J Prev Cardiol. vol. 24 (9), pp. 962-970.

\section{Т.П. Яворская}

\section{ЖИЗНЕСТОЙКОСТЬ КАК СОСТАВЛЯЮЩАЯ ПСИХОЛОГИЧЕСКОЙ АДАПТАЦИИ У ПАЦИЕНТОВ С ЦЕРЕБРОВАСКУЛЯРНОЙ ПАТОЛОГИЕЙ}

Обследовано 383 пациента с цереброваскулярной патологией на разных этапах течения болезни и 47 условно здоровых лиц. В исследовании использованы «Тест жизнестойкости по С. Мадди» и Бостонский тест на стрессоустойчивость. У пациентов с развернутой клинической картиной цереброваскулярной патологии определяются низкие показатели жизнестойкости. Больные после инсульта составляют группу высокого риска нарушения психологической адаптации вследствие сочетания комплекса дезадаптивных сомато-психологических факторов. Повышение стрессового риска сочетается со снижением жизнестойкости, что указывает на наличие общих звеньев психогенеза или факторов, задействованных в «антистрессовой» активности. Понимание проявлений психологического феномена жизнестойкости как внутриличностного ресурса по преодолению стресса у пациентов с соматическими заболеваниями, раскрывает широкие возможности в построении комплекса мероприятий медико-психологической помощи для пациентов с цереброваскулярной патологией на основе здоровьецентрированого подхода.

Ключевые слова: жизнестойкость, иереброваскулярная патология, медико-психологическая помощьв.

\section{T.P. Yavorska}

\section{HARDINESS AS A PART OF PSYCHOLOGICALADAPTATION IN PATIENTS WITH CEREBROVASCULAR PATHOLOGY}

Observed 383 patients with cerebrovascular pathology on different stage of diseases and 47 healthy persons. In research we used Hardiness Survey and Boston Stress Test. In patients with clinical manifestations of cerebrovascular pathology found lower hardiness rates. Patients after stroke constitute a group of the highest risk of development psychological disadaptation as a result of combining a complex of maladaptive somato-psychological factors. Increasing stress risk combined with a decreasing hardiness, indicating about presence of common parts of psychogenesis or factors involved in "anti-stress" activity. Understanding the context of psychological phenomenon such as hardiness as an interpersonal resource directed on coping with stress in patients with somatic diseases reveals wide opportunities in building a complex system of psychological help for patients with cerebrovascular pathology based on a healthcentered approach.

Key words: hardiness, cerebrovascular pathology, psychological help.

\section{Контактна інформація}

Надійшла до редакиії 10.05.2019

Яворська Тетяна Петрівна - кандидат медичних наук, лікар Харківської обласної клінічної лікарні - Центру екстреної медичної допомоги та медицини катастроф, асистент кафедри ультразвукової діагностики Харківської медичної академії післядипломної освіти МОЗ України.

Адреса: Україна, 61058, м. Харків, пр. Незалежності, 13, Харківська обласна клінічна лікарня; Україна, 61176, м. Харків, вул. Амосова, 58, ХМАПО.

Тел.: +380507059466.

E-mail: yavorska.tp@gmail.com.

ORCID: 0000-0001-7654-5195. 